\title{
Analysis the Results of Control and Elimination of Coal-Burning-Borne Endemic Fluorosis in Chongqing City
}

\author{
Wei Yan, Jun Xie, Xinshu Li, Shuang Zhou* \\ Disease Control and Prevention Center of Chongqing City, Chongqing, China \\ Email: ^82579314@qq.com
}

How to cite this paper: Yan, W., Xie, J., Li, X.S. and Zhou, S. (2018) Analysis the Results of Control and Elimination of Coal-Burning-Borne Endemic Fluorosis in Chongqing City. Open Journal of Epidemiology, 8, 145-152.

http://dx.doi.org/10.4236/ojepi.2018.83012

Received: July 26, 2018

Accepted: August 14, 2018

Published: August 17, 2018

Copyright (c) 2018 by authors and Scientific Research Publishing Inc. This work is licensed under the Creative Commons Attribution-NonCommercial International License (CC BY-NC 4.0).

http://creativecommons.org/licenses/by-nc/4.0/

\begin{abstract}
Objective: Discuss the analysis of the results of control and elimination of coal-burning fluorosis in Chongqing, and evaluate the effect of prevention and control. Methods: Dean's method was used to investigate the fluorosis for the local children whose ages ranged from 8 to 12 years old, the use of improved stoves in residential households, the drying of corn and pepper for human consumption, and the results were evaluated and discussed according to the national standard for the control and elimination of coal-burning fluorosis. Results: The prevalence rate of dental fluorosis borne-disease in children whose ages ranged from 8 to 12 years old was about $11.28 \%$ in 661 historically diseased villages in 100 townships and in 13 districts and counties of Chongqing city. The correct utilization rates of improved stoves, qualified improved stoves, and qualified stoves were $100 \%, 98.82 \%$, and $99.45 \%$, respectively. The correct drying rates of corn and pepper for human consumption were $99.88 \%$ and $99.75 \%$ respectively. There are 24 uncontrolled villages, 225 controlled villages, and 412 villages in eliminated disease zones in administrative villages. There are 4 villages and counties in uncontrolled, 4 in controlled, and 5 eliminated areas in districts and counties. Conclusion: Fluorosis borne-disease caused by coal-burning in Chongqing has reached the control and elimination targets of the twelfth Five-year plan.
\end{abstract}

\section{Keywords}

Coal-Burning Fluorosis, Control and Elimination, Evaluation

\section{Introduction}

Coal-burning fluorosis is a systemic chronic and accumulated poisoning disease which is caused by excessive intake of fluoride through water, air, and food in a 
high-fluorine environment. After nearly 30 years of health education as the forerunner, Chongqing has made general prevention and treatment in improving stoves and has achieved remarkable results. To evaluate the prevention and control effect of coal-burning fluorosis, we evaluated and eliminated the coal-fired fluorosis in our city from May to August 2015. The evaluation of the control and elimination of coal-burning fluorosis in the city is summarized as follows.

\section{Objects and Methods}

\subsection{Survey Objects}

Children whose ages were ranged from 8 to 12 years old and residents who lived in 661 coal-fired fluorosis historical villages of 100 townships from 13 districts in Chongqing were selected from May to August 2015.

\subsection{Investigation Material}

\subsubsection{Children's Dental Fluorosis}

The dental fluorosis was investigated in all children whose ages were ranged from 8 to 12 years old born locally, and the prevalence of dental fluorosis was calculated in the administrative village as a unit.

\subsubsection{The Use of Improved Stoves}

The use of improved stoves was to investigate the use of improved stoves in all historically endemic villages, calculate the rate of improved stoves, the rate of qualified improved stoves, and the correct utilization rate of qualified improved stoves.

\subsubsection{Drying of Corn and Pepper for Human Consumption}

The aim is to investigate the drying of corn and pepper for human consumption in all historically endemic villages and calculate the correct drying rate of corn and pepper for human consumption.

\subsection{The Municipal Review}

According to the results of the district self-inspection municipal review two districts, each district spot check 3 townships, each township spot check three administrative villages, review the dental fluorosis of all children aged between 8 to 12 years old born locally, the use of improved stoves and dry condition of corn and pepper for ten families consumption. Calculation of dental fluorosis prevalence, improved stoves rate and qualified rate of improved stoves, qualified improved stoves correct usage, for people to eat corn and chili right drying rate, compared with the districts self checking in line with the situation.

\subsection{Judgment Standard}

\subsubsection{Control Standard}

Qualified rate of improvement and correct utilization rate of stoves were over $90 \%$; the correct drying rate of corn and capsicum for human consumption in the endemic area reached over $90 \%$. The prevalence of fluorosis in children aged 
from 8 to 12 years of age born and living locally was less than $30 \%$.

\subsubsection{Elimination Standard}

Elimination of the standard qualified and improved cooking rate and the correct use rate of the stove were above 95\%; the correct drying rate of corn and pepper for human consumption was over $95 \%$; the prevalence of dental fluorosis in children aged from 8 to 12 years old who were born locally was $\leq 15 \%$.

\subsubsection{Elimination and Control Standards of District and County}

When the villages in the endemic villages are up to the standard of the control or elimination criteria, they can be judged as having achieved or eliminated goals. When $95 \%$ of the villages in the endemic district are up to the control or elimination standard, the district can be determined to meet the control or elimination criteria.

\subsection{Statistical Analysis}

Statistical analyses such as dental fluorosis rate and improved stoves rate were calculated by SPSS17.0 for Windows.

\section{Result}

\subsection{Basic Situation}

A total of 661 villages, 399,314 families, 142,705 population, and 91,070 children' age ranging from 8 to 12 years old were investigated in 13 districs and counties. And 66,162 children were examined, with a rate of $72.65 \%$.

\subsection{Children with Dental Fluorosis Situation}

7464 were detected from 66,162 children in the district, the dental fluorosis detection rate was about $11.28 \%$, the fluorosis index was about 0.14 , and the defect rate of dental fluorosis was about $0.29 \%$. According to the evaluation criteria for the control and elimination of dental fluorosis administrative village for children aged ranged from 8 to 12 , there are 426 villages less than or equal to $15 \%$, and 642 villages less than or equal to $30 \%$ (Table 1 ).

\subsection{Household Survey Status}

\subsubsection{Improved Stove Status}

A total of 399,314 households of improved stoves were investigated by the county and the rate of improved stoves was $100 \%$. The number of households with qualified stoves was 394,613 , and the rate of qualified stoves was $98.82 \%$. The number of households with compatible use was 392,441 , the correct utilization rate of qualified improved stoves was $99.45 \%$, and the actual number of recipient people was 1425,705 (Table 2).

\subsubsection{The Dry Condition of Corn and Pepper for Human Consumption} A total of 661 villages in 100 townships, towns, and counties in 13 districts and counties were investigated. The number of villages eating corn was 344 . The 
number of villages eating chili was 657, and the correct rate of drying pepper for human consumption was $99.75 \%$. There were 655 villages greater than or equal to $90 \%$, accounting for $99.70 \%$ of the total number of food villages. There were 655 villages greater than or equal to $95 \%$, accounting for $99.70 \%$ of the total number of food villages (Table 3).

\subsection{Municipal Review}

A total of 45 administrative villages in 15 townships and towns in 5 districts and counties were re-examined at the municipal level, and 257 villages were investigated by the county level. There were 18, 124, and 115 villages uncontrolled among the detected villages, controlled and eliminated, respectively. Municipal review since the evaluation result is not controlled villages of random number is 6 , check result for control, control and eliminate the village number $6,0,0$, respectively, at the municipal level review since the evaluation result for the control of the examined selected villages for 16 , the check result is not controlled, control and eliminate the village number respectively $0,0,16$, and self-evaluation of municipal review results to eliminate village of random number was 21 , check result is not control, control and eliminate the villages number respectively 0,0 , 21 , consistent with counties since the evaluation result.

\subsection{Ward to Determine}

According to the results of self-inspection of district and county and the review of municipal level, among 661 administrative villages in 100 towns and villages of 13 districts and counties, the prevalence rate of fluorosis teeth in children aged from 8 to 12 years old is $11.28 \%$, the rate of improved stoves is $100 \%$, the rate of qualified improved stoves is $98.82 \%$, and the correct utilization rate of qualified improved stoves is $99.45 \%$. According to the evaluation criteria of administrative village control and elimination, the number of uncontrolled, controlled and eliminated villages was 24,225 , and 412 , respectively. According to the evaluation criteria of district and county control and elimination, there were 4, 4, and 5 uncontrolled, controlled and eliminated counties, respectively (Table 4).

\section{Discussion}

Under the policy of government leadership, departmental cooperation, mass participation and health education as the forerunner of improved oven in Chongqing since 1982 in Wushan we first found coal-burning fluorosis, thanks to the efforts of the department of disease control and other departments, through the process of disease detection, etiology research, furnace modification (2 times), monitoring, health education, current situation investigation and stove application research, the prevention and control work has gone through 33 years, and remarkable achievements have been made in the prevention and control work [1] [2] [3] [4]. 1) The condition of children with fluorosis teeth was gradually 
Table 1. Self-inspection results of dental fluorosis in children aged ranged from 8 to 12 years old in coal-burning fluorosis areas of Chongqing.

\begin{tabular}{|c|c|c|c|c|c|c|c|c|c|}
\hline $\begin{array}{l}\text { County } \\
\text { name }\end{array}$ & $\begin{array}{c}\text { Number of } \\
\text { towns }\end{array}$ & $\begin{array}{c}\text { Number of } \\
\text { village }\end{array}$ & $\begin{array}{l}\text { Check the } \\
\text { number } \\
\text { of children }\end{array}$ & $\begin{array}{l}\text { Detected } \\
\text { cases }\end{array}$ & $\begin{array}{c}\text { Prevalence } \\
\text { rate }(\%)\end{array}$ & $\begin{array}{l}\text { Fluorosis } \\
\text { index }\end{array}$ & $\begin{array}{c}\text { Defect rate } \\
(\%)\end{array}$ & $\begin{array}{c}15 \% \text { or less } \\
\text { number of } \\
\text { village }\end{array}$ & $\begin{array}{c}30 \% \text { or less } \\
\text { number of } \\
\text { village }\end{array}$ \\
\hline Fengjie & 18 & 179 & 14,978 & 2309 & 15.42 & 0.18 & 0.50 & 93 & 179 \\
\hline Pengshui & 16 & 86 & 10,953 & 346 & 3.16 & 0.04 & 0.22 & 85 & 86 \\
\hline Qijiang & 3 & 19 & 1503 & 140 & 9.31 & 0.13 & 0.47 & 16 & 19 \\
\hline Qianjiang & 16 & 74 & 11,410 & 471 & 4.13 & 0.05 & 0.16 & 68 & 73 \\
\hline Wansheng & 2 & 14 & 1877 & 101 & 5.38 & 0.07 & 0.21 & 14 & 14 \\
\hline Wushan & 19 & 177 & 17,410 & 3086 & 17.73 & 0.22 & 0.21 & 69 & 163 \\
\hline Wuxi & 8 & 44 & 3182 & 532 & 16.72 & 0.25 & 0.69 & 22 & 41 \\
\hline Nanchuan & 2 & 3 & 330 & 38 & 11.52 & 0.12 & 0.00 & 2 & 3 \\
\hline Xiushan & 3 & 8 & 399 & 49 & 12.28 & 0.15 & 0.25 & 4 & 7 \\
\hline Shizhu & 3 & 7 & 614 & 48 & 7.82 & 0.12 & 0.16 & 7 & 7 \\
\hline Kanxian & 2 & 12 & 1731 & 250 & 14.44 & 0.15 & 0.00 & 8 & 12 \\
\hline Wulong & 3 & 7 & 549 & 42 & 7.65 & 0.09 & 0.00 & 7 & 7 \\
\hline Total & 100 & 661 & 66,162 & 7464 & 11.28 & 0.14 & 0.29 & 426 & 642 \\
\hline
\end{tabular}

Table 2. Results of self-inspection on improved stoves in Chongqing coal-burning fluorosis area.

\begin{tabular}{|c|c|c|c|c|c|c|c|c|c|}
\hline $\begin{array}{l}\text { County } \\
\text { name }\end{array}$ & $\begin{array}{l}\text { Number of } \\
\text { villages in } \\
\text { the ward }\end{array}$ & $\begin{array}{l}\text { Population of } \\
\text { villages in the } \\
\text { affected areas }\end{array}$ & $\begin{array}{c}\text { The number } \\
\text { of improved } \\
\text { stoves }\end{array}$ & $\begin{array}{c}\text { Improved } \\
\text { ovens rate } \\
\quad(\%)\end{array}$ & $\begin{array}{l}\text { The number } \\
\text { of qualified } \\
\text { households } \\
\text { for improved } \\
\text { stoves }\end{array}$ & $\begin{array}{l}\text { Improved } \\
\text { ovens pass } \\
\text { rate }(\%)\end{array}$ & $\begin{array}{l}\text { The correct } \\
\text { number of } \\
\text { households }\end{array}$ & $\begin{array}{c}\text { Correct } \\
\text { utilization } \\
\text { rate of } \\
\text { qualified } \\
\text { improved } \\
\text { stoves (\%) }\end{array}$ & $\begin{array}{c}\text { The number } \\
\text { of recipient } \\
\text { people }\end{array}$ \\
\hline Fengjie & 107,314 & 392,868 & 107,314 & 100 & 104,843 & 97.70 & 104,712 & 99.88 & 392,868 \\
\hline Pengshui & 48,621 & 204,844 & 48,621 & 100 & 48,474 & 99.70 & 48,454 & 99.96 & 204,844 \\
\hline Qijiang & 11,731 & 40,017 & 11,731 & 100 & 11,402 & 97.20 & 11,354 & 99.58 & 40,017 \\
\hline Qianjiang & 57,042 & 200,304 & 57,042 & 100 & 56,563 & 99.16 & 56,451 & 99.80 & 200,304 \\
\hline Wansheng & 12,697 & 44,472 & 12,697 & 100 & 12,639 & 99.54 & 12,620 & 99.85 & 44,472 \\
\hline Wushan & 102,280 & 336,299 & 102,280 & 100 & 101,614 & 99.35 & 99,849 & 98.26 & 336,299 \\
\hline Wuxi & 22,537 & 81,076 & 22,537 & 100 & 22,069 & 97.92 & 22,067 & 99.99 & 81,076 \\
\hline Yunyang & 15,382 & 49,355 & 15,382 & 100 & 15,374 & 99.95 & 15,341 & 99.79 & 49,355 \\
\hline Nanchuan & 2328 & 8875 & 2328 & 100 & 2313 & 99.36 & 2303 & 99.57 & 8875 \\
\hline Xiushan & 2190 & 8409 & 2190 & 100 & 2188 & 99.91 & 2188 & 100 & 8409 \\
\hline Shizhu & 3141 & 10,198 & 3141 & 100 & 3114 & 99.14 & 3083 & 99.00 & 10,198 \\
\hline Kanxian & 10,851 & 38,867 & 10,851 & 100 & 10,823 & 99.74 & 10,823 & 100 & 38,867 \\
\hline Wulong & 3200 & 10,121 & 3200 & 100 & 3197 & 99.91 & 3196 & 99.97 & 10,121 \\
\hline Total & 399,314 & $1,425,705$ & 399,314 & 100 & 394,613 & 98.82 & 392,441 & 99.45 & $1,425,705$ \\
\hline
\end{tabular}


Table 3. Results of self-inspection on the drying of corn and pepper for human consumption in Chongqing coal-burning fluorosis area.

\begin{tabular}{|c|c|c|c|c|c|c|c|c|c|c|}
\hline \multirow[b]{2}{*}{$\begin{array}{l}\text { County } \\
\text { name }\end{array}$} & \multirow[b]{2}{*}{$\begin{array}{l}\text { Number of } \\
\text { townships }\end{array}$} & \multirow[b]{2}{*}{$\begin{array}{l}\text { Number of } \\
\text { villages }\end{array}$} & \multicolumn{4}{|c|}{ Corn drying } & \multicolumn{4}{|c|}{ Pepper drying } \\
\hline & & & $\begin{array}{l}\text { Number } \\
\text { of edible } \\
\text { villages }\end{array}$ & $\begin{array}{l}\text { Correct } \\
\text { drying } \\
\text { rate }(\%)\end{array}$ & $\begin{array}{l}90 \% \text { or } \\
\text { greater } \\
\text { number of } \\
\text { the villages }\end{array}$ & $\begin{array}{c}95 \% \text { or greater } \\
\text { number of the } \\
\text { villages }\end{array}$ & $\begin{array}{l}\text { Number } \\
\text { of edible } \\
\text { villages }\end{array}$ & $\begin{array}{l}\text { Correct } \\
\text { drying } \\
\text { rate (\%) }\end{array}$ & $\begin{array}{l}90 \% \text { or } \\
\text { greater } \\
\text { number of } \\
\text { the villages }\end{array}$ & $\begin{array}{c}95 \% \text { or } \\
\text { greater } \\
\text { number of } \\
\text { the villages }\end{array}$ \\
\hline Fengjie & 18 & 179 & 44 & 100 & 44 & 44 & 179 & 100 & 179 & 179 \\
\hline Pengshui & 16 & 86 & 56 & 99.95 & 56 & 56 & 84 & 100 & 84 & 84 \\
\hline Qijiang & 3 & 19 & 10 & 99.57 & 10 & 10 & 19 & 98.53 & 19 & 19 \\
\hline Qianjiang & 16 & 74 & 38 & 99.00 & 36 & 35 & 72 & 98.64 & 70 & 70 \\
\hline Wansheng & 2 & 14 & 12 & 99.93 & 12 & 12 & 14 & 99.44 & 14 & 14 \\
\hline Wushan & 19 & 177 & 108 & 100 & 108 & 108 & 177 & 100 & 177 & 177 \\
\hline Wuxi & 8 & 44 & 40 & 100 & 40 & 40 & 44 & 100 & 44 & 44 \\
\hline Yunyang & 5 & 31 & 19 & 100 & 19 & 19 & 31 & 100 & 31 & 31 \\
\hline Nanchuan & 2 & 3 & 1 & 100 & 1 & 1 & 3 & 100 & 3 & 3 \\
\hline Xiushan & 3 & 8 & 4 & 100 & 4 & 4 & 8 & 100 & 8 & 8 \\
\hline Shizhu & 3 & 7 & 1 & 100 & 1 & 1 & 7 & 100 & 7 & 7 \\
\hline Kanxian & 2 & 12 & 9 & 100 & 9 & 9 & 12 & 100 & 12 & 12 \\
\hline Wulong & 3 & 7 & 2 & 100 & 2 & 2 & 7 & 100 & 7 & 7 \\
\hline Total & 100 & 661 & 344 & 99.88 & 342 & 341 & 657 & 99.75 & 655 & 655 \\
\hline
\end{tabular}

Table 4. Results of comprehensive evaluation on control and elimination of coal-burning fluorosis in Chongqing.

\begin{tabular}{|c|c|c|c|c|c|c|}
\hline $\begin{array}{l}\text { County } \\
\text { name }\end{array}$ & $\begin{array}{l}\text { Number of } \\
\text { township }\end{array}$ & $\begin{array}{l}\text { Number of } \\
\text { village }\end{array}$ & $\begin{array}{c}\text { Uncontrolled } \\
\text { Village } \\
\text { number }\end{array}$ & $\begin{array}{c}\text { Control the number } \\
\text { of village }\end{array}$ & $\begin{array}{l}\text { Eliminate the } \\
\text { number of village }\end{array}$ & $\begin{array}{l}\text { Determine the } \\
\text { results }\end{array}$ \\
\hline Fengiie & 18 & 179 & 1 & 87 & 91 & Control \\
\hline Pengshui & 16 & 86 & 0 & 1 & 85 & Eliminate \\
\hline Qijiang & 3 & 19 & 0 & 3 & 16 & Control \\
\hline Qianjiang & 16 & 74 & 4 & 6 & 64 & No control \\
\hline Wansheng & 2 & 14 & 0 & 0 & 14 & Eliminate \\
\hline Wushan & 19 & 177 & 15 & 101 & 61 & No control \\
\hline Wuxi & 8 & 44 & 3 & 19 & 22 & No control \\
\hline Yunyang & 5 & 31 & 0 & 0 & 31 & Eliminate \\
\hline Nanchuan & 2 & 3 & 0 & 1 & 2 & Control \\
\hline Xiushan & 3 & 8 & 1 & 3 & 4 & No control \\
\hline Shizhu & 3 & 7 & 0 & 0 & 7 & Eliminate \\
\hline Kanxian & 2 & 12 & 0 & 4 & 8 & Control \\
\hline Wulong & 3 & 7 & 0 & 0 & 7 & Eliminate \\
\hline Total & 100 & 661 & 24 & 225 & 412 & \\
\hline
\end{tabular}


alleviated. The prevalence rates were $70.00 \%$ (1985), 51.05\% (2001), $27.97 \%$ (2009), and $11.28 \%$ (2015). In 2009, there were no new cases of skeletal fluorosis in the city [5]. 2) Proper prevention and control measures. In the 1990s, more than 130,000 households completed the transformation of simple stoves in $\mathrm{Wu}$ shan, Qianjiang and Pengshui counties. From 2004 to 2012, a total of 282,755 households in 13 disease areas and counties were engaged in fluoride-reducing back-smoke furnaces and biomass gasifiers. 3) Status monitoring of disease and prevention. Fluorosis caused by coal burning in our city has been monitored in three stages. From 1991 to 2000, dental fluorosis of children, air fluorine, and urine fluorine were mainly monitored in Wushan and Pengshui. From 2001 to 2009, the monitoring of children's dental fluorosis, air fluorine, children's urine fluorine, and improved stoves was carried out in Wushan and Qianjiang. From 2010 to the present, monitoring has been carried out in Wushan, Fengjie and Wuxi, focusing on children's fluorosis, children's urine fluorine, adult skeletal fluorosis, improvement of stoves for prevention and control, and changes in hygienic behaviors. The monitoring results showed that children's fluorosis was alleviated, children's urine fluorine was gradually decreased, no new patients with fluorosis were found, the number and quality of stoves were significantly improved, the health knowledge of endemic fluorosis was improved, and health behaviors were significantly improved [6] [7].

The results of this evaluation showed that the prevalence rate of dental fluorosis in children aged from 8 to 12 years old was $11.28 \%$, the correct utilization rate of improved stoves, qualified improved stoves, and qualified improved used stoves were $100 \%, 99.82 \%$ and $99.45 \%$, respectively, and the correct drying rates of corn and pepper for human consumption were $99.88 \%$ and $99.75 \%$, respectively. All the indicators have reached the target of the 12th five-year plan of the state, which fully shows that after more than 30 years of prevention and control, the disease condition in the sick areas has significantly decreased, the effect of prevention and control measures in improved oven is obvious. The health behavior of the residents in the affected areas has been improved significantly, and remarkable achievements have been made in prevention and control.

It is suggested that in future prevention and control work, combined with the results of this evaluation, appropriate measures should be taken according to local conditions and classified guidance should be given to carry out appropriate improved oven, enhanced monitoring, and enhanced health education work in uncontrolled villages to promote the improvement of health behaviors of residents in the affected areas. Health education, oven maintenance and establishment of a post-management system for all-coal fluorosis in the control village to further reduce the disease; health education and a long-term mechanism for the prevention and control of coal-burning fluorosis was established to keep the elimination in the village [8] [9] [10].

\section{Conflicts of Interest}

The authors declare no conflicts of interest regarding the publication of this paper. 


\section{References}

[1] Sun, D.J. (2004) Research on Hot Issues in the Prevention and Control of Endemic Fluorosis Should Be Strengthened. Chinese Journal of Local Medicine, 2, 4-6.

[2] Sun, Y.F. and Yu, G.Q. (2007) Research Progress and Prevention Strategy of Endemic Fluorosis Caused by Coal Burning Pollution. Chinese Journal of Preventive Medicine, 3, 227-229.

[3] An, D. (2013) Current Situation and Prospect of Prevention and Control of Endemic Fluorosis Caused by Coal Burning Pollution. Foreign Medicine (Medical Geography), 1, 1-3.

[4] Xie, C.J. (1990) Harm of Coal-Fired Fluorosis and Countermeasures for Social Prevention and Control. China Rural Health Management, 7, 39-40.

[5] Yan, W., Xiao, B.Z., Luo, J. and Liao, W.F. (2009) Analysis of Results of Investigation on the Prevention and Control of Endemic Fluorosis Caused by Coal Burning Pollution in Chongqing. Journal of Tropical Medicine, 2, 202-205.

[6] Yan, W., Xie, J. and Li, L. (2010) Analysis of Key Monitoring Results of Endemic Fluorosis Caused by Coal Burning Pollution in Chongqing from 1991 to 2007. Public Health and Preventive Medicine, 2, 29-33.

[7] Yan, W., Xiao, B.Z., Luo, J. and Wu, B. (2007) Analysis of Monitoring Results of Endemic Fluorosis Caused by Coal Burning Pollution in Qianjiang District from 2001 to 2005. Journal of Tropical Medicine, 2, 175-177.

[8] Yun, Y.F. and Lu, Q.W. (1995) Investigation on Consolidation of Fluorosis Lesions in Coal-Burning Contaminated Areas of the Yangtze River Three Gorges. Chinese Journal of Endemic Disease Control, 2, 109-110.

[9] Zhang, B.Y., Li, D.S., Liang, Y., et al. (2011) Analysis on the Follow-Up Management Effects of Improved Stoves in Guizhou Province on the Prevention and Treatment of Fluorosis Caused by Coal Burning Pollution. Chinese Journal of Local Disease Control, 4, 273-275.

[10] Xiao, B.Z., Chen, J., Yan, W., et al. (2009) Epidemic Factors and Countermeasures of Fluorosis Caused by Coal Burning in Chongqing. Journal of Tropical Medicine, 8, 954-958. 